М. В. Бойчук

\title{
ОЦІННА ФУНКЦІЯ НЕОЛОГІЗМІВ У ЗАГОЛОВКАХ ПЕРІОДИЧНИХ ІНТЕРНЕТ-ВИДАНЬ
}

Бойчук М. В. Оцінна функція неологізмів у заголовках періодичних інтернет-видань.

Простежено закономірності виконання оцінної функції неологізмами, вживаними у заголовках періодичних інтернет-видань, з'ясовано типи лінгвоодиниць, що виступають носіями оцінки, визначено характер донорської зони, звідки залучаються концепти-еталони.

Ключові слова: афікс, неологізм, оказіоналізм, оцінка, концепт-еталон, композит, лексема.

Бойчук М. В. Оценочная функция неологизмов в заголовках периодических интернет-изданий.

Прослежены закономерности выполнения оценочной функции неологизмами, используемыми в заголовках периодических интернет-изданий, выяснены типы лингвоединиц, выступающих носителями оценки, определена донорская зона, откуда привлекаются концепты-эталоны.

Ключевые слова: аффикс, неологизм, окказионализм, оценка, концепт-эталон, композит, лексема. 
Boychuk M. Estimated function of neologisms in the headlines of periodic online publications.

The patterns of evaluation function of neologisms used in the titles of periodical online publications are traced, the types of linguistic units being the bearers of assessment are found, the nature of donor area from where the concept-pattern are being involved in are defined.

Key words: affix, neologism, occasionalism, assessment, concept-pattern, composite, lexical unit.

У тезах Празького лінгвістичного гуртка зазначено, що мова як продукт людської діяльності разом 3 цією діяльністю має цільову спрямованість. Вивчення мовної діяльності як засобу спілкування засвідчує той факт, що найбільш звичайним завданням мовця, яке простежується найчіткіше, $\epsilon$ вираження. Спираючись на цю тезу, дослідники роблять висновок про потребу функціонального підходу до проведення лінгвістичного аналізу. Крізь призму такого бачення мова виступає як система засобів вираження, «яка служить якійсь певній меті. Жодне явище в мові не може бути зрозуміле без урахування системи, до якої воно належить» [13, с. 17]. Потреба вираження мовцями певного значення (а також «супровідних смислів») виступає мотиваційною основою «створення» мовної системи, іiі еволюціонування, оскільки, як констатує Е. Косеріу, сама по собі система залишається «незмінною»: вона не містить причин для будь яких змін і не розвивається сама по собі [3]. Про потребу функціонального підходу до розгляду мови говорить i А. Мартіне: оскільки конкретні мови, дослідження яких являє собою найперше завдання лінгвіста, виступають передусім засобами спілкування, спостерігати за ними й описувати їх варто насамперед у їхньому функціонуванні [6]. Яскраве вираження функціонування мовної системи знаходить у динаміці лексичного складу. Тому актуальним бачиться завдання вивчення неологічної лексики в різних аспектах. Значною мірою воно виконане у грунтовних працях С. Срмоленко, М. Кочергана, К. Ленець, О. Мельничука, С. Карпіловської, Н. Клименко, А. Москаленка, В. Русанівського, Н. Сологуб, О. Стишова, Л. Струганець, О. Тараненка та багатьох інших. У ряді кандидатських досліджень (Д. Мазурик, С. Лук'яненко, М. Романюк, О. Калякіна, А. Калєтнік, Т. Коць, Н. Стратулат та ін.) конкретизована низка загальних теоретичних положень неології. Здійснено лексикографічну фіксацію нової лексики (Д. Мазурик, А. Нелюба). Розгорнуто широкий фронт досліджень оказіональних структур. Перш за все це докторські праці Ж. Колоїз (розглянуто концептуальні питання української оказіональної деривації) і Г. Вокальчук (опрацьовано оказіональні лексичні новотвори в українській поезії ХX ст.). Свій внесок у вивчення явища оказіональності здійснено низкою кандидатських дисертацій. Це роботи Т. Юрченко (простудійовано структурно-семантичний i стилістичний аспекти оказіоналізмів у творчості П. Загребельного), Н. Адах (опрацьовано семантику, функції, прагматику авторських лексичних новотворів у поезії В. Барки), О. Жижоми (вивчено індивідуально-авторські новотвори у поетичному дискурсі 80-90-х рр. ХХ століття), Н. Гаврилюк (досліджено словотворчість поетів-неокласиків у контексті поетичного мовлення 20-30-х 
років XX ст.), С. Бузько (простудійовано оказіональні лексичні утворення в постмодерних художніх текстах), О. Турчак (розглянуто оказіоналізми в мові української преси 90-х рр. ХX ст.), К. Брітікової (розроблено тему «Узуальне та оказіональне в інноваціях сучасної української мови: тенденції оновлення лексико-словотвірної категорії назв особи»). Як показує аналіз, у дослідженні неолексики нагромаджено значний теоретичний i практичний матеріал. Однак існує потреба у розгляді питань, пов'язаних 3 виконанням неологізмами оцінної функції у заголовках періодичних інтернет-видань. Нею визначається актуальність пропонованої розвідки. Мета дослідження - з'ясувати, як неологізми виконують оцінну функцію в заголовках періодичних інтернет-видань. Об'єктом дослідження виступають уживані в заголовках періодичних інтернет-видань нові номінативні одиниці, в яких реалізується категорія оцінки.

Створення неоодиниці найчастіше має на меті дати яскраву образнооцінну характеристику зображуваному явищу. Формальний і смисловий план таких одиниць відкриває широкий простір суб'єктові комунікації для втілення номінативно-зображальних інтенцій. Це випливає з особливостей людської свідомості, адже поряд 3 номінативно-класифікаційною діяльністю, що обслуговує пізнавальні потреби людини, воно також природно реагує на дійсність і в емоційному плані, коли кваліфікує позначуваний об'єкт крізь призму свого сприйняття його як приємний / неприємний, корисний / непотрібний, надзвичайно великий чи дуже малий, інтенсивний чи слабкий у своєму вияві, такий, що являє собою особистісне чи суспільне «добро» або «зло». «Потрапляння до значень слів кваліфікаційної діяльності свідомості й вираження в ньому емотивних реакцій суб'єкта мовлення на очікуване ним і створює, як писав свого часу Ш. Баллі, «експресивне забарвлення мовних фактів»« [14, с. 203]. Виразно експресивними мовними фактами виступають оказіональні неологізми, що досить потужним компонентом входять до медіалексики. Неологізми цього типу в мові сучасних ЗМІ функціонують як 3 позитивно-оцінною, так i негативно-оцінною маркованістю. Оцінна функція оказіоналізмів пов'язана, зокрема, із тим, що мас-медіа часто створюють так званий «чорний піар» [7, с. 8]. Будучи складними у структурно-семантичному плані одиницями тексту, оказіоналізми, порівняно з узуальними словами, завжди мають поліфункціональний характер. Через це у вдало створених авторських одиницях постійно втілюється виражальний потенціал мови. По-новому називаючи відповідні денотати (загальнолітературні слова цього позбавлені), оказіоналізми використовуються для передачі нових семантичних, стилістичних, емоційно-експресивних відтінкв. Така їхня особливість дає змогу яскравіше втілити авторські інтенції [2, с. 14].

Сучасні мас-медіа важко уявити без виконання ними оцінної функції. Їхнє повноцінне функціонування вже неможливе без надання оцінки подіям суспільного життя в різних його виявах (політичному, 
економічному, культурному), а також без відповідного аргументування цих оцінок [11]. У процесі такої оцінки медіатекст виробляє у реципієнта відповідне ставлення до того чи іншого явища, об’єкта, події, формує їх позитивні чи негативні образи, показує їх відповідність чи невідповідність цінностям, культивованим у суспільстві. Оцінка в загальнонауковому контексті, на думку дослідників, - «це така думка про предмет, яка виражає його характеристику з огляду на категорії цінності, а цінність - це будь-який предмет певного зацікавлення, бажання, прагнення тощо. Поняття цінності всеохопне: людина оцінює все, що було, є, буде, може бути i могло би бути. Аксіологія - одна 3 фундаментальних проблем гуманітарного і соціально-наукового пізнання, оскільки аналіз цінностей входить як аксіологічний компонент не тільки у філософські, але й соціологічні, психологічні, етнологічні та інші концепти» [4].

Категорія оцінки належить до універсальних мовних категорій, що перебувають у тісних зв'язках з пізнавальною діяльністю людини. Увага до цієї мовної категорії зумовлена антропоцентризацією розвитку сучасної лінгвістики. Унікальність категорії оцінки випливає з того, що вона здатна не лише здійснювати відображення ціннісної сутності чогось (об'єкта) для когось (суб’єкта), але водночас і формувати світоглядні позиції та впливати на поведінку значної кількості людей [5].

Однією 3 дефінцій лінгвістичного терміна «оцінка» $\epsilon$ «складник конотативного компонента семантичної структури мовної одиниці, який репрезентує ставлення носіїв мови до позначеного за абсолютною шкалою «добре - нейтрально (байдуже) - погано» і відносною шкалою «краще так само добре - так само нейтрально - так само погано - гірше» [12, с. 438-439]. Т. Космеда пропонує розглядати оцінку у мовознавстві як структурно-семантичну, функціональну, прагмасемантичну категорію, яка формується рядом концептів («схвалення / осуд», «згода / незгода», «симпатія / антипатія») [4].

Отже, сучасне лінгвістичне розуміння оцінки спирається на іiі здатність виражати мовними засобами відповідну цінність певного об'єкта, яка піддається тестуванню на предмет відповідності чи невідповідності його системі засадничих концептів соціуму за допомогою абсолютної чи відносної шкали, виробленої його культурною свідомістю. Оцінка має об'єктивно-суб'єктивний характер, оскільки в результатах актів суб'єктивного сприйняття відображаються особливості об'єктивного світу. Згадана суб'єктивність сприйняття - величина змінна й відносна. Вона детермінується хронотопними й особистісними параметрами суб'єкта пізнавальної (і відповідно - оцінної) діяльності (час і місце життя, рівень історико-культурного розвитку, політичні уподобання тощо).

Оцінну структуру формують такі компоненти:

a) cуб' $є к m$ оцінки (індивід / частина соціуму / соціум), який і виступає своєрідною точкою відліку, з якої починається процес оцінювання; 
б) власне оцінка (операція виявлення / невиявлення в об’єкті відповідних ознак і матеріального закріплення цього факту);

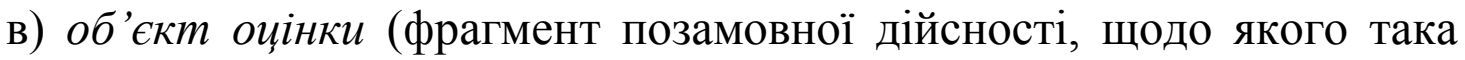
операція застосовується);

г) предмет оцінки (адресат, той, на кого спрямована оцінка);

г) оцінна шкала (предметна шкала, що має зони позитивного, нейтрального чи негативного);

д) стереотип (позначений стійкістю, тривалістю та національною специфічністю семіотично значущий еталон або зразок норми, характерний для певної мовної культури [10].

Оцінка може виражатися різними засобами: експліцитно (iї носіями виступають оцінні слова) та дескриптивними висловлюваннями 3 їх імпліцитним змістом. Вибір залежить від авторських інтенцій [9, с. 30]. Якщо говорити про оцінку, що наявна у слові як його семантичний компонент, то, на думку дослідників, вона являє собою оцінне значення, закріплене в семантичній структурі слова, в якому знаходить своє втілення ставлення носія мови (колективного чи індивідуального) до позначеного словом об'єкта позамовної дійсності, що відбувається у межах схеми «добре / погане», «схвальне / несхвальне», «позитивне / негативне», «корисне / шкідливе» та ін. [10].

У функціональному семантико-стилістичному плані категорія оцінки в публіцистичному дискурсі організовується за польовим принципом i являє собою сукупність різнорівневих мовних засобів. Їх об'єднання відбувається на основі наявності аксіологічного значення i виконання відповідної функції. Використання цього комплексу має на меті виразити ставлення автора мовлення (тексту) до навколишньої дійсності для забезпечення ефективності процесу комунікації у сфері 3МI [11]. У структурі функціонально-семантичного поля оцінки в сучасній українській мові I. Онищенко виділяє такі концепти, як симпатія / антипатія, схвалення / несхвалення, похвала / осуд, згода / незгода, подяка, бажання, зачікавлення, докір, заборона, звинувачення, загроза, критика тощо [8, с. 6]

Номінативно-оцінна функція, виконувана неологізмами, має тісний зв'язок з функцією образності, проте щодо неї виступає як первинна [2, с. 9-10]. Аналізовані неологізми виносять на поверхню своєї формальносмислової структури прагмарелевантні оцінні смисли. «Прагматична інформація оказіоналізмів виражається в оцінних протиставленнях типу «погано - добре». Оцінка є прагматичним компонентом семантики слова, який тісно пов'язаний із конотацією» [1, с. 12].

Оцінка, носіями якої виступають неологізми в заголовках періодичних інтернет-видань, може виражатися найрізноманітнішими засобами: від дериваційного афікса до лексеми. Використання цих засобів у структурі одиниць вищого рівня маркує оцінністю все утворення. Афіксальне втілення оцінки представлене не так широко. Суфіксальні 
одиниці - явище порівняно малопродуктивне. Оцінна суфіксація часто негативна: долгановщчина (УП, 08.06.01), піарщина (УП, 30.07.08), ЖЕКівщина (ВВ, 06.08.08), Замковенщчна, Потебеньщчина (УП, 13.01.01), тейпгейтщчина (УП, 11.01.02), мажоритарщзина (УП, 18.01.01), коаліційщина (УП, 23.09.08), Клюєвщ⿻ина (УП, 06.10.06), азаровщчина (УП, 19.01.04, 26.02.07; 30.10.07), Ківаловщчина (УП, 30.03.07), фірташизація (УП, 12.10.07), вестернізація (УП, 11.03.09), лукашенкізація (УП, 13.10.04), макдональдизачія (УП, 11.03.09) путінізація (УП, 03.12.08), кірілізація (УП, 29.05.11), білорусизація (УП, 30.03.11), есдепізація (УП, 18.02.05; 11.01.07), ірландизачія (УП, 08.01.04), барбосизація (УП, 05.08.08), кабакізація (УП, 11.03.09), НАТОналізація (УП, 09.04.08), васалізація (УП, 11.03.01). Негативну оцінку несуть суфіксальні деривати, що називають осіб за належністю до того чи іншого політичного угруповання: противсіхи (УП, 01.03.11; 11.05.11), тимоменки (УП, 07.11.08), медведчуки (УП, 04.04.08), табачники (УП, 29.04.11), Ющенки, Турчинови, Клички (УП, 25.05.08), януковичі (УП, 08.05.08; ІБ, 10.05.10), Тягнибоки (УП, 28.08.07).

Значно продуктивніше представлена префіксація. Ситуативну динаміку суспільних протиборств і протистоянь автори оказіоналізмів відображають за допомогою новотворів 3 префіксами анти- i не(з серйозною перевагою першого): антитемник (УП, 30.04.04), антирейтинг (DU, 16.05.11), антипоступка, антикомпроміс (УП, 02.10.06), aнтипатріот (УП, 14.08.08), антиющенківец̧ь (УП, 20.11.05), антиглобаліст (УП, 09.10.01), антиющенко - «конституційні зміни» (УП, 22.03.04), антикучміст (УП, 10.02.01; 01.05.01; 06.08.02), антикризовик (УП, 15.11.06), антиющенківський (УП, 15.06.01), антикучмістський (УП, 11.05.01), антищербанівський (УП, 09.11.06), антиТабачний (ІБ, 31.03.10), антикорупційний (ЛП, 18.03.10), антиєвропейський (УП, 21.04.11), антиНАTO (УП, 21.12.05), антимайдан (УП, 13.01.10), антикучмізм (УП, 27.04.01), антимафія (УП, 22.05.01), антиукраӥнізачія (УП, 18.05.06), недепутат (УП, 14.06.07), нереформатор (УП, 14.02.01), неформат (УП, 14.02.08), непідписант (УП, 06.11.07; 27.11.07).

Входячи до полілексемних номем, оцінну семантику такі деривати формують довкола себе: антибейсбольний наказ Юрія ЗМІрнова - «внутрішній наказ МВС, спрямований на створення кураторів 3МІ» (УП, 06.11.01).

Оцінка несправжності, фальшивості, невідповідності еталону виражена за допомогою префіксів псевдо-, лже-, квазі-: псевдо-«Пора» (УП, 01.09.07), псевдокрадіжки (ЛП, 02.04.09), псевдоДАІиники (УП, 03.05.11), псевдо-Тимошенко - «М. Замковенко» (УП, 04.09.07), лжепорист (УП, 28.08.07), лжепасинок (УП, 22.10.07), квазіавторитаризм (УП, 27.05.11).

Оцінка новизни порівняно 3 відомим уже явищем формується шляхом використання префікса нео-: неофеодалізм (УП, 21.09.09), 
необольшевизм (УП, 07.08.07), нео-СНД (УП, 03.12.05), неоімперіалістичний (ІБ, 28.07.10). Таку саму функцію може виконувати і лексема відповідної семантики, що входить до багатокомпонентної назви: новий кокаӥновий рекордсмен - «Перу, що вийшла на перше місце у світі 3 вирощування коки - рослини, 3 листя якої виготовляють кокаїн» (ЛП, 24.06.10). Оцінювання високої якості об'єкта мовець здійснює, використовуючи префікс тоn-: топ-контрабанда (MN, 20.04.11). Серед префіксальних одиниць трапляються синонімічні: антиолігарх (УП, 13.06.01) // неолігарх (УП, 26.12.00). Виявлено випадки, коли в результаті префіксації одного компонента оцінної модифікації зазнає ціла усталена конструкція: кредит не/довіри (УП, 07.02.01), не/наукова фантастика (УП, 01.06.01).

Префіксально-суфіксальні утворення перебувають на периферії: освиніти (УП, 20.05.08).

Набільш поширеним способом творення оцінних оказіоналізмів, вживаних у заголовках інтернет-видань, виступає використання лексичних компонентів. Адресат тексту «сприймає оцінку новотвору, закладену автором у це слово. Здебільшого оцінка мотивується твірними основами слів» [1, с. 12]. Лексичні елементи функціонують як дериваційні засоби та структурні компоненти аналітичних номем, парафразів і трансформованих сталих висловів.

Номінативно-оцінна функція, як зазначає О. Жижома, найбільш характерна для композитів і юкстапозитів. Вони, якщо порівнювати їх 3 простими словами, наділені пізнавально-оцінною семою [2, с. 9-10]. Щодо складних слів О. Турчак констатує їх досить широке використання зі стилістичною метою в мові преси 90-х років XX ст. Такі структурносемантичні утворення створюють умови для вираження найрізноманітніших суб'єктивно-експресивних відтінків думки, оскільки їхня природа передбачає поєднання в межах одного слова різних основ та коренів. Складні слова наділені величезними стилістичними можливостями, оцінною силою, поняттєвою, пізнавальною й естетичною місткістю [15, с. 13].

Нові одиниці композитної природи «успадковують» оцінну семантику базових словосполучень, проте через формально-семантичну сконденсованість виражають ii значно виразніше (пор. гривньопад (УП, 15.08.06) < падіння гривні): кадротрус (УП, 02.06.11), кнопкодав (УП, 24.03.05; ФП, 12.05.11), пляможер (УП, 05.06.02), путінбачення (ВЕ, 21.08.09), інформкіллерство (УП, 30.01.01), енергосвиня (УП, 03.11.09). Інколи одиниці такого типу вміщують іншомовні компоненти (політдурдом (I-P, 21.07.10) або й цілком складаються 3 них (Copland - «поліцейська країна (країна копів)» «Україна») (УП, 04.04.01).

Юкстапозити 3 аксіологічною функцією можна поділити на дві групи. До першої з них зараховуємо одиниці, в яких оцінна лексемакомпонент займає фінальну позицію: Kiнax-onmuмicm (УП, 25.05.01), 
президент-янгол (УП, 27.06.03), депутат-перебіжчик (УП, 06.07.01), фінал-апофеоз (УП, 01.03.06), батьки-нелюди (ЛП, 11.11.10), автомобільмрія (УП, 24.10.01), прем'єр-«кремезні плечі» (УП, 12.01.01), дівчина«Дюймовочка» (УП, Tablo ID, 12.05.11), держава-мутант (УП, 23.04.08), партія-аутсайдер (УП, 18.06.09), місто-мільйонник (I-P, 09.05.11), жінкаепоха (УП, 14.03.03), фітнес-прокол (УП, 13.03.08), будинок-фантом (УП, 12.07.07), олігарх-футтболіст (УП, 25.08.01). Відповідно структури, де оцінна лексема-компонент стоїть в ініціальній позиції, входять до другої групи: горе-батьки (ЛП, 18.01.11), горе-мати (ЛП, 24.02.09), горесоиіологи (УП, 11.09.07), горе-бюджет (УП, 20.09.06), горе-перевізник (ЛП, 23.06.11), «Підрахуй»-Ківалов (УП, 29.04.11), PR-війна (РіK, 19.02.10), медіа-війна (УП, 21.08.04), ерзач-реформи (УП, 17.01.08), VIР-колеса (VG, 11.03.06), Vip-пенсіонер (УП, 25.02.09; 07.06.07), VIP-діmu (УП, Таblo ID, 07.04.11), VIP-зал (УП, 09.06.05), vір-дорога (УП, 27.08.10), VIP-гараж (УП,Tablo ID, 15.04.11), VIР-пенсія (УП, 25.05.11), VIP-машина (ФП, 27.04.11; УП, 10.06.11).

Посилення оцінки демонструють одиниці комбінованого характеру: дитинка-сиротинка (УП, 08.12.08).

Оцінного значення набувають структури, неможливі 3 погляду традиційної граматики: трошки опозиціонер (УП, 30.10.01).

На рівні одиниць розчленованої природи оцінну семантику несе один 3 компонентів, що приводить до появи оцінної функції у всієї структури: епідемія крадіжок (УЗІ, 27.12.10), фрлешмоб «Рік у ярмі» (C, 25.02.11), акція «День гніву» (Д, 13.05.11). Виразну оцінку дають конструкції, в яких стикаються одиниці різного (високого й низького) звучання конституційні «посиденьки» - «обговорення проекту Конституції» (УП, 02.09.09), політичний «кугутизм» - «поведінка жадібних і хвалькуватих політиків» (I-P, 08.06.11), євробалачки з продовженням - «депутатські пристрасті довкола будівництва стадіону до Євро-2012 у Львові» (ЛП, 25.10.08), всенародний пофігізм - «суцільна байдужість населення» (УП, 01.07.03), беззуба Феміда - «поблажливість українського судочинства щодо справ, до яких причетні політики, посадовці різних рангів або їхні родичі» (ЛП, 31.01.09).

Оцінка може здійснюватися шляхом зіставлення понять. Зручно для цього підходять загальновідомі концепти - ті поняття семіотичного універсуму, що входять до інформаційної компетенції адресата мовлення. Вони можуть виступати у двох варіантах: а) 3 номінативною метою сполучатися 3 ситуативно зумовленими компонентами: John Kennedi history number two - «отруєння Ющенка» (С, 29.12.10), Майдан-2 «Податковий Майдан» (ЛП, 11.01.11), «чорна мітка» Луцеенку - «проект постанови про звільнення міністра внутрішніх справ Юрія Луценка» (УП, 12.05.09), віра, надія $і$ любов Кучми - «Партія регіонів, Народнодемократичної партія і партія «Трудова Україна» (УП, 17.08.01), закон 
Архімеда від Партії регіонів - «подвійні стандарти сучасного правосуддя» (УП, 21.08.08), замах на «священну корову» - «переписування Верховною Радою української Конституції» (УП, 09.07.01), «порнооскар» для Леоніда Даниловича - «антинагорода Кучмі за заслуги на лінгвістичній ниві» (УП, 14.03.01), троянський кінь для Януковича - «С. Тігіпко» (УП, 27.04.09), иарі зі жезлами - «автоінспектори, що зловживають службовим становищем» (ЛП, 03.06.10), «ахіллесова n'ята» Януковича «міністр транспорту М. Рудьковський і міністр з питань надзвичайних ситуацій Н. Шуфрич» (УП, 05.09.07); б) являти собою переосмислені усталені конструкції (семантичні неологізми): королівство кривих дзеркал - «Україна 2001 року» (УП, 07.02.01), «2 в 1» - «поєднання посади першого секретаря політради 3 посадою голови СПУ» (УП, 13.11.07), порохова діжка - «ракетне пальне» (УП, 06.04.09), смітник радіоактивних відходів - «нова дослідницька установка 3 переробки відпрацьованого ядерного палива в Харкові» (УП, 14.04.10), чєлобітниє иарю - «питання громадян до Януковича» (УП, 24.02.11). Варіації першого різновиду можуть мати різний характер.

Трансформуючи сталі вислови у структури неологічного характеру, автор переносить ознаки базової структури на похідну, порівнюючи два денотати, оцінюючи порівнюваний крізь призму ознак еталонного: велика китайська вода (ЛП, 25.06.11). Інколи автор вдається для наведення варіантів оцінки певного об'єкта, вибір одного з яких мусить зробити читач: Ющенко: Гамлет чи Мойсей? (УП, 26.05.01), Друзі мої, чудовий / жахливий наш союз! (УП, 17.10.01).

Зручним засобом вираження оцінки виступає перифрастичне порівняння: Дон Корлеоне по-українськи - «корупція в Держінспекції по контролю за цінами при Міністерстві економіки» (УП, 15.12.09), український Берлусконі - «Р. Ахметов» (УП, 27.10.06), український Бальиерович - «В. Ющенко» (УП, 05.05.01), украӥнський Сталін «ідеальний очільник держави» (УП, 18.12.02), російське НАТО - «ОДКБ» (BE, 03.08.09). При цьому донорська зона еталонних компонентів демонструє досить широкий спектр концептів: Григорій Перший «Г. Суркіс» (УП, 12.06.07), Інна Гебельсівна - «I. Богословська» (УП, 20.03.09), тигр украӥнської політики - «О. Ляшко» (УП, 02.12.09), старий валет - «А. Мартинюк» (УП, 13.12.07), кривавий друг Ющенка «М. Саакашвілі» (УП, 03.11.07), намі Муаммари - «президенти країн» (УП, 28.02.11), нові Морози - «зрадники обіцянок виборцям» (УП, 18.11.07), Honeymoоn Януковича - «перший час перебування Віктора Януковича на посаді Президента України» (УП, 02.03.10), виборчий Хелоуїн - «вибори 2010» (УП, 23.10.04), газовий «гоп-стоп» для України $і$ Європи - «зрив поставок газу в Свропу» (УП, 10.01.09).

У процесі дослідження виявлено своєрідні корелятивні оцінні пари, інтегральною ознакою для яких виступає використання того самого 
концепту-еталона: украӥнський Робін Гуд - «Ю. Тимошенко» (ВЕ, 01.06.11) // Робін Гуд навпаки - «В. Янукович» (УП, 11.06.11). Водночас можна вести мову про певну поширеність деяких концептів-еталонів (пор. також і ніжинські робінгуди - «ніжинські злочинці, які стали на боротьбу 3 незаконним обігом наркотиків під прикриттям міліції» (УП, 07.07.11).

Оцінне значення несуть і конструкції оксюморонного характеру, коли поєднуються виразно непоєднувані компоненти. Така семантична полярність структурних одиниць, поряд 3 потужною образністю, забезпечує їхню оцінну маркованість, яка зазнає посилення: соціалістичний олігарх «почесний президент Маріупольського меткомбінату ім. Ілліча В. Бойко» (УП, 20.11.06), капіталістичні соціалісти по-украӥнськи - «мільярдери та мультимільйонери у виборчому списку ПР» (УП, 28.08.07), комуно-олігарх (УП, 20.04.01; 02.08.06), міліціонер-порушник (ЛП, 28.05.09), лікарзбоченець (ЛП, 20.09.08), баба-кінь - «травесті-діва Монро» (УП, Tablo ID, 09.02.11), міліціонер-хабарник (ЛП, 26.06.08; СІTI, 26.01.11), адвокатхабарник (СITI, 21.06.11), викладач-хабарник (ЛП, 28.05.09), суддякорупціонер (УП, 03.03.09).

У процесі формування оказіональних одиниць аксіологічної природи автор може вдаватися до антонімічного калькування. Суть цього прийому полягає в утворення нової номеми шляхом надання компонентам дериваційної бази протилежного значення словотвірним засобами: жовтохолодна контрреволючія - «реставрація кучмізму через два роки після виборів 2004 р» (УП, 21.11.06) < жовтогаряча револючія «протести проти фальсифікації виборів 2004 р.».

Серед лексичних засобів вираження категорії оцінки можна виділити такі типи неологізмів: а) зовнішні запозичення (з англійської (loser (УП, 19.05.01), рейдер (УП, 23.10.06; 02.12.06; ЛП, 10.06.10) та російської мови (їх більше: безпрєдєл (ЛП, 30.07.09), одобрямс (УП, 25.08.10), попса (УП, 26.07.00), «йолка» (ФП, 07.04.11), заказуха (УП, 18.04.01; 02.04.09), розводилівка (УП, 21.11.02) і б) внутрішні запозичення (ошуст (ЛП, 25.10.08).

Потужний оцінний заряд несуть семантичні неологізми: тушка (ФП, 28.03.11), Рада «зависла» (УП, 09.09.09), Росія «сватає» Україні свій захист ... (УП, 02.04.11), феодал - «В. Лозінський» (УП, 07.07.09), панщчина «використання військовослужбовців для політичної агітації» (УП, 03.08.07). Їхня оцінність значною мірою детермінується мотиваційною базою: иумахер «водій, що зловживає швидкістю» (ЛП, 25.11.10) > Михаель Шумахер «гонщик, семиразовий чемпіон світу, володар численних рекордів Формули1, найуспішніший пілот за всю історію автоспорту».

Оцінка може здійснюватися шляхом застосування мовної гри. Такі одиниці розраховані як на зорове сприйняття (ПіднеВІЛЬНЕ ТБ (УП, 06.11.07), Б’ЮTi (УП, 14.01.02), MESSIon Impossible - «негативна характеристика гри футбольної збірної Аргентини» (CCU, 08.07.11), так і 
на легку впізнаваність еталонного прототипу, що забезпечує оцінне звучання: політикантроп (УП, 28.04.09), лібераст (УП, 12.05.11), федераст (УП, 01.08.07), федерастичний лохотрон - «ідея федералізації України» (УП, 07.12.05), потебень (УП, 17.02.01), бігморди (УП, 02.08.07; 09.08.07; 17.09.07; 01.12.09).

Отже, лінгвістичне уявлення про оцінку грунтується на здатності мовних засобів виражати відповідну цінність певного об'єкта, що входить до картини світу того чи іншого соціуму. Сфера його багатоспектного життя зазнає постійного оцінювання системою ЗМІ, які дають, транслюють i аргументують його, вдаючись до усього спектру лінгвальних засобів. У результаті реципієнтові пропонується оцінка певного об'єкта, на основі якої він може формувати своє ставлення до нього.

Виразними мовними засобами, використовуваними у заголовках інтернет-видань, виступають різнотипні інновації. Серед проаналізованих неологізмів оцінну функцію здебільшого виконують оказіоналізми, що випливає 3 їхньої функціональної природи. Категорія оцінки в аналізованих одиницях може виражатися найрізноманітнішими засобами. Це - афіксація, семантична деривація, використання лексем (як словотвірних компонентів у процесах формуваання композитів i юкстапозитів, а також структурних складників полілексемних утворнень).

Донорська зона концептів-еталонів сягає усього семіотичного універсаму людства. Деякі концепти-еталони позначені активністю використання. Дослідження функціонального навантаження оказіоналізмів має значну наукову перспективу, адже функціональність цих лінгвоодиниць закладена в їхній номінативній природі, специфічні вияви якої детермінуються авторськими інтенціями.

\section{Література}

1. Адах Н. А. Авторські лексичні новотвори в поезії Василя Барки: семантика, функції, прагматика : автореф. дис. на здобуття наук. ступеня канд. філол. наук : спец. 10.02 .01 «Українська мова» / Н. А. Адах. - К., 2009. -20 с.

2. Жижома О. О. Індивідуально-авторські новотвори у поетичному дискурсі 80-90-х років XX століття : автореф. дис. на здобуття наук. ступеня канд. філол. наук : спец. 10.02.01 «Українська мова» / О. О. Жижома. - Д., 2003. - 18 с.

3. Косериу Э. Синхрония, диахрония и история (Проблема языкового изменения) [Електронний pecypc]. - Режим доступу: http://www.classes.ru/grammar/150.new-in-linguistics-3/source/worddocuments /_1.htm

4. Космеда Т. А. Аксіологічні аспекти прагмалінгвістики: засоби вираження категорії оцінки в українській та російській мовах [Електронний ресурс] : автореф. дис. на здобуття наук. ступеня доктора філол. наук : спец. 10.02.01 «Українська мова»; 10.02 .02 «Російська мова» / Т. А. Космеда. - Х., 2001. 32 c. - Режим доступу: http://disser.com.ua/contents/3043.html

5. Крамаренко М. Л. Аксіологічна прагмасемантика англомовного рекламного тексту [Електронний ресурс] : автореф. дис. на здобуття наук. ступеня канд. філол. наук : спец. 10.02.04 «Германські мови» / М. Л. Крамаренко. - Д., 2005. - 21 с. - Режим доступу: http://disser.com.ua/ contents/3041.html

6. Мартине А. Основы общей лингвистика [Електронний ресурс]. - Режим доступу: http://www.classes.ru/grammar/150.new-in-linguistics-3/source/worddocuments/_1.htm

7. Мітчук О. А. Нові слова та їх значення у мові мас-медіа Рівненщини (1995-2005 рр.) : автореф. дис. на здобуття наук. ступеня канд. філол. наук : спец. 10.01.08 «Журналістика» / О. А. Мітчук. - Львів, 2006. $-17 \mathrm{c}$. 
8. Онищенко I. В. Категорія оцінки та засоби їі вираження в публіцистичних та інформаційних текстах : автореф. дис. на здобуття наук. ступеня канд. філол. наук : спец. 10.02.01 «Українська мова»/ I. В. Онищенко. - Дніпропетровськ, 2005. - 20 с.

9. Петришина Е. Ю. Авторская оценка как способ отражения концептуального смысла романа (на материале романа Дж. Фаулза «Женщина французского лейтенанта») / Е. Ю. Петришина // Вестник Московского государственного областного университета. Серия «Лингвистика». - 2011. - № 1. - С. $30-37$.

10. Равлюк С. І. Аксіологічна лексика і фразеологія художньо-публіцистичних виступів 90 -х років XX століття [Електронний ресурс]: автореф. дис. на здобуття наук. ступеня канд. філол. наук : спец. 10.02.01 «Українська мова» / С. І. Равлюк. - К., 2003. - 23 с. - Режим доступу: http://disser.com.ua/contents/3040.html

11. Серажим К. С. Категорії оцінки й аргументації в публіцистичній мові газети [Електронний pecypc]. - Режим доступу: http://journlib.univ.kiev.ua/index.php?act=article\&article=1240

12. Сучасна лінгвістика : термінологічна енциклопедія / [авт.-уклад. Селіванова О. О.]. - Полтава : Довкілля-К, 2006. - 716 с.

13. Тезисы Пражского лингвистического кружка // Пражский лингвистический кружок: сб. статей. М. : Прогресс, 1967. - С. 17-41.

14. Телия В. Н. Типы языковых значений : Связанное значение слова в языке / Телия В. Н. - М. : Наука, 1981. - 269 c.

15. Турчак О. М. Оказіоналізми в мові української преси $90-х$ років ХХ століття : автореф. дис. на здобуття наук. ступеня канд. філол. наук : спец. 10.02.01 «Українська мова» / О. М. Турчак. Дніпропетровськ, 2005. - 19 с.

$\begin{array}{lll} & \\ \text { DU } & - & \text { http://daily.com.ua/ } \\ \text { MN } & - & \text { http://www.mukachevo.net } \\ \text { PiK } & - & \text { http://www.pik.cn.ua/ } \\ \text { VG } & - & \text { http://vgolos.com.ua/ } \\ \text { BB } & - & \text { http://val.ua/politics/chernigov/192407.html } \\ \text { BE } & - & \text { http://www.epochtimes.com.ua/ } \\ \text { Д } & - & \text { http://www.day.kiev.ua/ } \\ \text { IБ } & - & \text { http://www.otherside.com.ua } \\ \text { I-P } & - & \text { http://rep-ua.com/ } \\ \text { ЛП } & - & \text { http://www.lvivpost.net } \\ \text { C } & - & \text { http://sprotiv.org } \\ \text { CCU } & - & \text { http://www.champion.com.ua } \\ \text { CITI } & - & \text { http://ifcity.in.ua } \\ \text { У3I } & - & \text { http://uzinform.com.ua/ } \\ \text { УП } & - & \text { http://www.pravda.com.ua } \\ \text { ФП } & - & \text { http://www.4post.com.ua }\end{array}$

